Article

\title{
Improving Governance Systems of National Parks: How the Instrument of a 'Governance Scan' Can Contribute
}

\author{
Jasper Hessel Heslinga ${ }^{1, *}$ and Stefan Hartman ${ }^{1,2}$ (D) \\ 1 European Tourism Futures Institute, Academy of Leisure and Tourism, NHL Stenden University, \\ P.O. Box 1298, 8900 CG Leeuwarden, The Netherlands; stefan.hartman@nhlstenden.com \\ 2 Department of Cultural Geography, Faculty of Spatial Sciences, University of Groningen, \\ P.O. Box 800, 9700 AV Groningen, The Netherlands \\ * Correspondence: jasper.heslinga@nhlstenden.com
}

Citation: Heslinga, J.H.; Hartman, S. Improving Governance Systems of

National Parks: How the Instrument of a 'Governance Scan' Can Contribute. Sustainability 2021, 13, 10811. https://doi.org/10.3390/ su131910811

Academic Editor: Fabio Carlucci

Received: 23 August 2021

Accepted: 25 September 2021

Published: 29 September 2021

Publisher's Note: MDPI stays neutral with regard to jurisdictional claims in published maps and institutional affiliations.

Copyright: (C) 2021 by the authors Licensee MDPI, Basel, Switzerland. This article is an open access article distributed under the terms and conditions of the Creative Commons Attribution (CC BY) license (https:// creativecommons.org/licenses/by/ $4.0 /)$.

\begin{abstract}
This paper presents a diagnostics tool that we refer to as a 'governance scan' and discusses how this tool can contribute to improving governance systems of National Parks. This governance scan combines an analytical framework and an approach to have better understanding of these governance systems. Understanding how National Parks are managed is crucial to achieve improvements and steer towards more sustainable future situations. Governance systems are a fundamental aspect of this, being understood as "associational networks of public, private, civil society actors and how they engage in the making, setting and implementation of rules at various geographical scales". How these systems are organized and function in practice can greatly shape conservation and development outcomes and hence future states of National Parks. The purpose of this paper is to; (1) elaborate on how this scan is rooted in the literature to explain its theoretical foundation and (2) step-by-step instruct how it is made applicable to use in practice. As an illustrative example, we discuss lessons learned from the application of the governance scan in the real-life context of the recently established 'New Land' National Park, located in The Netherlands. We conclude that the scan works as a diagnostics tool, to provide an overview of governance systems in place, facilitate knowledge transfer and discussions among different stakeholders, and set priorities in decision-making processes.
\end{abstract}

Keywords: sustainable tourism; protected areas; landscape management; resilience; governance; stakeholder management; tourism policy and planning

\section{Introduction}

National Parks have a long history and tradition [1]. The concept of a National Park was coined in the United States 150 years ago and has since spread to other parts of the world. Many National Parks find themselves more and more in the process of transition [2]. In recent years, the debate is increasingly focused on the changing role of National Parks. It is no longer solely about fulfilling conservation and protection goals [3]. National Parks are increasingly challenged to anticipate to several societal needs $[1,4,5]$, such as emerging processes such as climate change, pollution/urbanisation $\left(\mathrm{CO}_{2}, \mathrm{NOx}\right)$, and especially in the context of tourism: increasing visitor pressure [5,6]. National Parks are challenged to be(come), at the same time, both robust to endure and cope with possible factors that cause disturbance and flexible to adapt to changing needs, challenges and opportunities that continually arise [7]. Hence, robust means that parks have a certain richness and resilience that makes them resistant to impact or disruption. Flexible means that the parks are able to move along with and co-evolve to the dynamics of society. To be able to co-evolve requires (the capacity for) adaptation [8]. Adaptation can involve nature development or species management, embedding new functions such as tourism and recreation or housing, implementing new revenue models, new organizational structures, etc. Ideally, processes of adaptation will enrich the qualities and values of a National Park and thus strengthen 
their robustness. Responding to social developments and anticipating what is to come also has implications for the way in which the governance of National Parks is implemented [9].

In processes of transition, National Parks face many challenges in particular governance issues. Whilst nature protection and conservation were traditionally largely governmental affairs, more often those responsibilities lie less with governments and are increasingly shared with all kinds of other area parties [10]. This raises many questions: What leeway is there in policy, legislation and regulations for the adaptation and enrichment of the landscape? Is it possible to expand these boundaries? Should the objectives of National Parks be revised? How to arrange the management and development of the parks? Who are or should be involved in this? And in what composition?

To manage National Parks in a sustainable way, it is crucial to understand the underlying governance systems in National Parks [11]. Governance systems are understood in this paper as "associational networks of private (market), civil society (usually NGO) and state actors" and how they engage "in rule-making, rule-setting and rule implementation at a variety of geographical scales" [12,13]. While we are aware of the fact that the concept of 'governance' is heavily debated in both practice and academic, we also observe that a structured and analytical approach to understand and assess systems of governance for National Parks is currently lacking. Such an approach would be helpful, as it provides an overview of all the elements that relate to governance and how this forms a coherent whole. In this paper, we endeavor to find out how systems of governance of the National Parks are arranged and how these could possibly be better arranged. To facilitate this, we have developed a diagnostic tool called 'the governance scan' to unravel the complexity of governance processes [11]. The purpose of our paper is to; (1) elaborate on how this scan is rooted in the literature to explain its theoretical foundation and (2) step-by-step instruct how it is made applicable to use in practice

We illustrate (rather than providing a full case study, which is not the purpose of this paper) the applicability of the tool, by drawing on overarching findings from the National Park 'Nieuw Land' located in The Netherlands. This National Park received the formal status of a National Park in 2018 after a successful application process. The authors took part in the planning and design phase of the application process and were able to test the diagnostic tool in practice as part of this process. The purpose of this illustrative example is not to provide detailed case specific information on National Park 'Nieuw Land' itself. Our focus lies on the overarching findings and lessons observed from this example, are used in this paper to illustrate the usage of the governance scan as well as critically reflect on its implementation.

In our paper, we introduce the concept of governance in Section 2 and explain why the existing governance models are limited for managing National Parks in the context of the contemporary challenges that needs to be addressed. In Section 3 we introduce 'the governance scan', explain how it was developed and demonstrate how it can contribute to practice as a diagnostic tool to improve governance systems of National Parks. In the conclusion, we discuss and critically reflect on how the scan can help actor networks to improve governance systems of National Parks.

\section{Theory}

\subsection{Why Existing Governance Models Are Limited}

Governance is discussed a lot in both academic and practice, but sometimes it is unclear what is the concept means, which makes application in practices rather difficult. In this paper, the term "governance" refers to the way organizational and authoritarian structures are organized (see detailed definition in Section 1). The term is often linked to the shift from government to governance. In the case of 'government', the policy-making and decision-making is arranged from the central government. Governance is about involving more stakeholders in governance and management than governments alone $[14,15]$. Governance is characterized by a variety of flexible arrangements for the management of National Parks in a complex and uncertain world [16-18]. A clear understanding of the 
governance of a National Park is important in order to effectively and efficiently manage its conservation and development, but also to be able to implement matters such as the involvement of parties, financing, etc. $[19,20]$. To understand how a governance system works and potentially can be steered, it is important to unravel these layers of complexity around governance systems [11]. Several influential scholars have done this in the past and form the solid basis of our paper.

For the explanation of governance, a further division can be made, essentially involving three aspects. Drawing on Swyngedouw [12], governance is about the whole (the "system") of who is involved in and what is done in:

(1) the process of planning and policy making ("rule making")

(2) the actual decisions ("rule setting")

(3) what is done in practice ("rule implementation")

It is important for the sustainable future of National Parks to set up a governance system that carefully considers these aspects. A system that can safeguard and strengthen the management and development of the National Park's qualities and values. A system that is also supported by stakeholders. The tricky thing about National Parks is that the parks are very different in terms of physical and environmental conditions, size of the designated surface, human uses and infrastructures, rules and regulations, land ownership, management structures, financial arrangements, etc. To a greater or lesser extent, parks have their own (historic) development trajectory that shapes the current state and (sometimes strongly) shapes the possibilities for its future development path. This means that what works in one park cannot be identically or easily transferred to another park. Although best practices can provide useful insights, it is an illusion that there is one answer when it comes to the best model for a governance system of National Parks. Each area therefore requires customization and a tailor-made approach that aligns with its unique characteristics and local context.

There are several models available that can provide inspiration to help National Parks set up a governance system. The IUCN lists four typical governance models [21,22]:

A. Governance by government The government is the leading authority, either directly or indirectly (delegate power). Possibility multiple governmental levels or departments are involved.

B. Shared governance The roles and responsibilities are dispersed over multiple stakeholders such as governments, private sector, semi- or non-governmental or societal organisations, host-communities.

C. Private governance One of more private stakeholders, largely land and property owners, are responsible or take responsibility for the protection, conservation, management, development of the National Park.

D. Governance by indigenous peoples and local communities Local communities take the lead in the use, management and development of the National Park.

These governance models largely overlap with the typology of governance for tourism policy analysis by Hall [23] shown in Figure 1 below. 


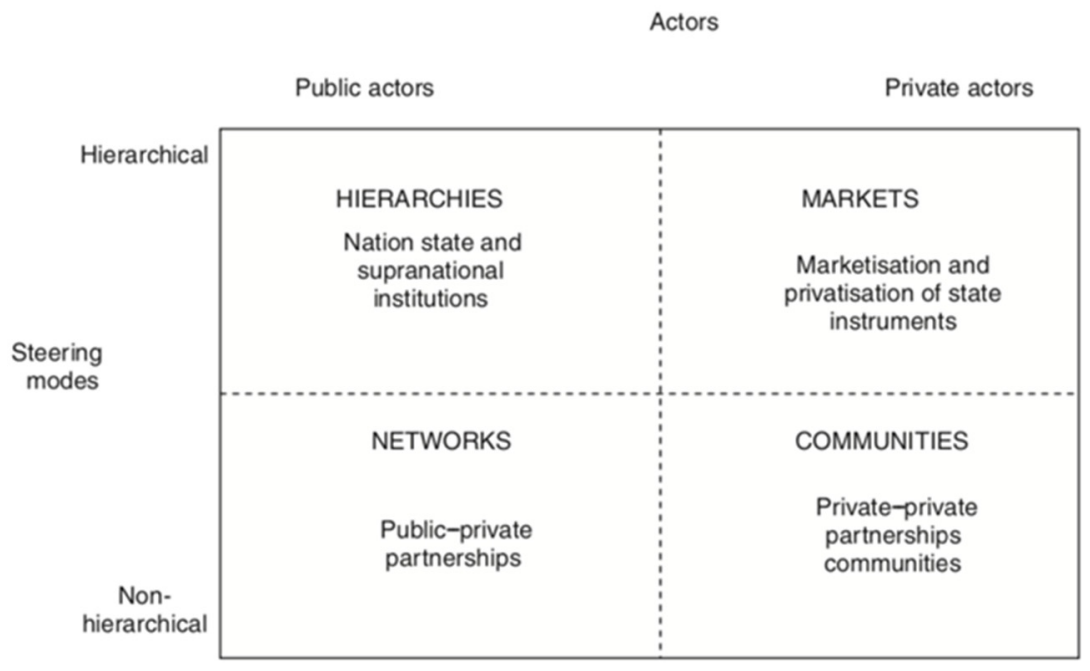

Figure 1. Frameworks of governance typology [23].

Whereas different theoretical models are differentiated in literature they tend to not always reflect real-life cases. We have observed three issues that show why this is problematic. First, most models are ideal-typical and cannot simply be found one-on-one in reality. In practice, there is often a mixed form. Although shared governance at a park level can seemingly cover the load well, it is different within National Parks: locally it can vary from places where ownership and/or responsibilities lie strictly with private individuals, site managing organizations, governments, associations, local communities, etc. Second, models for governance do not fit one-on-one, because parks are often, as it were, composite areas of different protection regimes. Withing the administrative boundaries, this can vary from strictly protected and inaccessible places to places where developments, functions and initiatives are possible - for example aimed at tourism and recreation. Such parts of the park can each fall under the responsibility of a different party. Moreover, the tendency is that National Parks are increasingly positioned as part of wider geographical areas and their development processes. This implies looking beyond administrative boarders and connecting to new stakeholders, potentially complexifying the governance system. Third, governance is not something "static", but is always evolving and under development. This can be a growth model (evolutionary governance), a dynamic model with a focus on the ability to respond adequately and anticipate social changes (adaptive governance) and a model aimed at reassessing underlying structures, agreements and actions-because these are always considered temporary and adaptable (reflexive governance) [7,24-26]. These issues should be taken into account and adequately addressed when designing a new governance model.

\subsection{Developing the Governance Scan as a Diagnostic Tool for National Parks}

The previous reflection on the existing models imply that the governance scan should provide a dynamic model, that allows for customization to fit with each unique case. This allows for a better grip on the design of the "governance systems" for National Parks. This is important, because governance systems are quite complex [16]: often a diverse mix of actors, strategies and instruments that, partly due to this diverse mix, create connections between levels of scale and between domains and, thus, create the available 'possibility space' in policy for conservation and development at the same time [20]. The choices for the design of a governance system have a major influence on the way in which coalitions of parties (whether or not) work together effectively and efficiently and arrive at actions and interventions that enrich areas-and thus bridge the gap between preservation/risk avoidance and on the other hand developing/seizing opportunities.

For developing the governance, and characteristics that a governance system should ideally meet, we used the principles of "good governance" that were distinguished in 
academic literature. As our starting point we used the seven principles: (1) Legitimacy; (2) Transparency; (3) Accountability; (4) Inclusivity; (5) Honesty; (6) Connectedness; (7) Resilience provided by Lockwood (2010). For each principle, a number of outcomes are given as to what these principles might look like in practice.

These governance principles are of a fairly general nature. Therefore, customization is required in order to be able to apply them properly in practice and in the specific context of National Parks. The above principles are general in nature. It therefore requires customization in order to apply the principles properly in practice and in the specific context of National Parks. This also happens within the National Parks of World Class program by the Dutch Ministry of Economic Affairs. These general good governance principles have, for example, been (partly) adopted and, together with other principles for good governance from other bodies (such as IUCN), have been (freely) translated into a number of criteria that are important for National Parks and the implementation of the governance systems that should provide further guidance to the conservation and development of those parks.

There is:

- A clear ambition and direction, including financing structure

- Legitimacy and support

- Professionalism, leadership and strength

- Transparency and a clear decision-making structure

- Accountability

- Participation, co-ownership and control

- Room for innovation

- An adaptive capacity

- Room for training/education and training

Taking inspiration from these advances in conceptualizing aspects and principles of governance systems for National Parks, we have developed a pragmatic governance scan and applied this scan in practice.

\subsection{The Governance Scan}

The scan is essentially a matrix that you can use as a tool to map out your own governance system (see Figure 1 below). In order to keep this matrix clear and applicable in practice, the 'good governance' principles that Lockwood distinguishes, together with the more pragmatic criteria described above have been clustered in 4 overarching design principles for governance [27]. Those are:

1. Participation

2. Legitimacy

3. Flexibility

4. Influence

These can be found on the $\mathrm{X}$-axis of the matrix. The Y-axis (vertical) contains 3 generic aspects of a "policy cycle" that should be incorporated into (almost) every governance system. The further application in practice is explained in more detail in the next section. The scan can be used in three different ways. First, the governance scan can be used in a descriptive way to gain a better understanding of how the governance system of a National Park is currently structured. Second, the scan can be used in an action-oriented way to draw up a change plan. The schedule must then be completed twice: once for the current situation and once for the desired future situation. This makes it possible to determine what differences there are between the desired situation and the current situation, to what extent these can be bridged, what is needed for this and at what pace this should/can be to happen. The outcome is a roadmap for the design of the governance system in the coming years. Third, the toolkit can be used comparatively by comparing and comparing the different governance systems of the National Parks, whereby experiences can be exchanged and lessons learned from best practices. 


\section{Method and Materials: The Application of the Governance Scan in 4 Steps}

The application of the governance scan in practice requires further explanation. Governance systems are complex, because many factors are interrelated and influence each other [28]. However, this can become easy to map out when using the governance scan and the accompanying matrix. Based on 4 steps, this section will go deeper into matrix itself and how it can be used (see Figure 2). In order to better understand the matrix, the generic aspects of the governance system on the $X$-axis are explained (step 1) and the design principles of the governance system on the Y-axis are discussed (step 2). In addition, the method for completing the matrix will be briefly explained by means of an online form (step 3). Finally, it is discussed how the different cells in the matrix can be "scored" based on the degree of satisfaction (step 4).

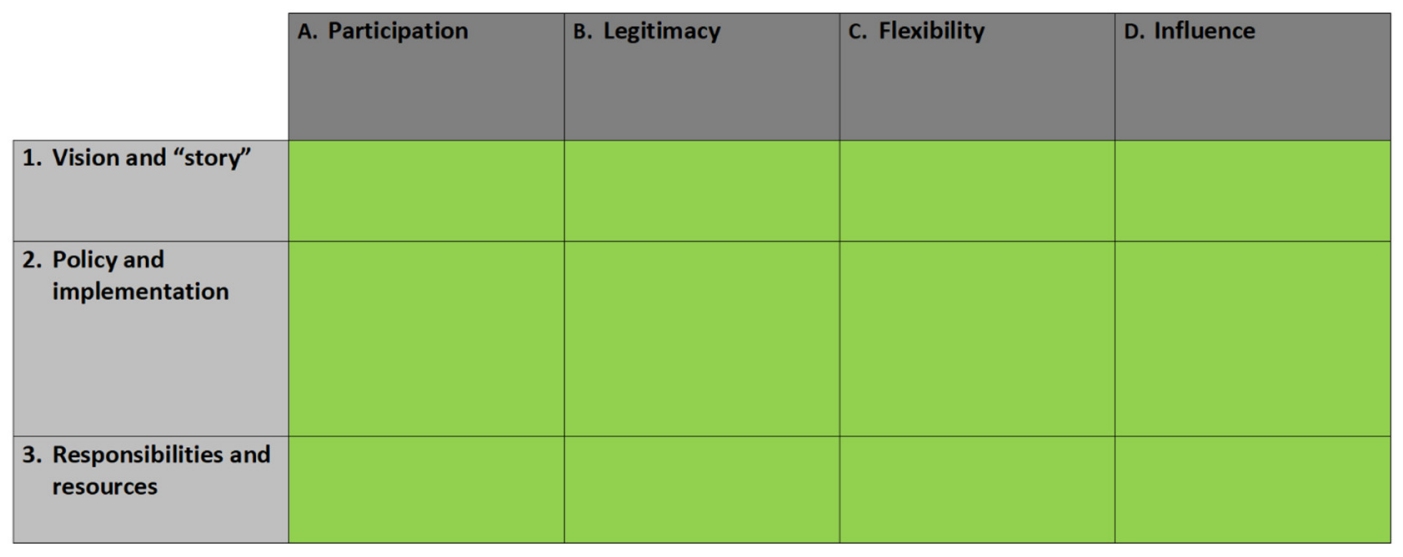

Figure 2. The simplistic matrix of the governance scan (source: authors).

Step 1: "The generic aspects of the governance system"

On the vertical axis of the matrix there are three generic aspects of a governance system that are (almost) always addressed in the management of National Parks. For these aspects it is important, in the first instance, to find out all relevant information. This concerns information that is largely recorded in policy documents, strategic plans, area visions, implementation programs, organization charts, process descriptions and so on. To interpret these aspects, an indicative set of guiding questions are given below are provided help users to identify the correct information:

1. Vision \& Story Is there a sense of urgency? Is there an area specific story or clear vision with goal, ambition, direction?

2. Policy \& Implementation Are policy frameworks in place? Has the implementation been properly arranged, e.g., by means of an implementation agenda and a program/project office? What actions are there with regard to information and communication? What about mandate for those responsible?

3. Resources \& Responsibilities How are finances arranged? Are resources such as money and time available? Is there a result obligation? Is there accountability? Are resources freely disposable or are they labeled with activities of the lender? Or, are they intended to initiate innovation?

Step 2: "The design of the governance system"

On the horizontal axis there are four design principles for governance (based on the literature study described in Section 2). This concerns choices with regard to the interpretation and implementation of those principles in practice. This information cannot be fully deduced from written documents. Partly it concerns the attitude and behavior of people and parties in practice. This is not necessarily laid down in procedures and protocols. Considerations and choices based on (political) preference, for example, influence the effective use of possibly scarce resources, the desire to speed up or act decisively, etc. A 
number of guiding questions are provided below to interpret these principles identify the correct information and can also be found in Figure 3:

A. Participation How inclusive is the system? Which parties are involved? Which parties are excluded? What is the scope, for example only parties within certain (administrative, managerial or landscape) boundaries? How easy or difficult is it for parties to exert influence/participate?

B. Legitimacy Is there support? Or is it more about consent or respect for the choices made? Is there being transparent? Is it clear to stakeholders how accountability is given and to whom? Are decisions taken at the right level? Is there a mandate?

C. Flexibility To what extent is there room for new stakeholders, new projects, new insights, new initiatives? Who decides whether someone will join or drop out? Is there a regular evaluation of whether assignment and management still fit together?

D. Influence Is there a strong leader? Is there decisiveness and effectiveness? Does influence come from "above" or "below on"? Is the degree of control clear to everyone? Is there (joint) ownership? Does influence come through formal or informal lines?

\begin{tabular}{|c|c|c|c|c|c|}
\hline & $\begin{array}{l}\text { Design of } \\
\text { governance systems }\end{array}$ & A. Participation & B. Legitimacy & C. Flexibility & D. Influence \\
\hline $\begin{array}{l}\text { Aspects of the } \\
\text { governance system }\end{array}$ & Description & $\begin{array}{l}\text { - } \text { Scope } \\
\text { - Allied in coalition } \\
\text { - Inclusivity } \\
\text { - } \\
\text { Honesty }\end{array}$ & $\begin{array}{l}\text { - } \text { Support } \\
\text { - Transparancy } \\
\text { - Structure of } \\
\text { decision-making } \\
\text { - }\end{array}$ & $\begin{array}{ll}\text { - } & \text { Renewal } \\
\text { - } & \text { Development } \\
\text { - } & \text { Innovation } \\
\text { - } & \text { Adaptivity }\end{array}$ & $\begin{array}{l}\text { - } \text { Control } \\
\text { - Ownership } \\
\text { - Leadership } \\
\text { - } \text { Clout power }\end{array}$ \\
\hline 1. Vision and "story" & $\begin{array}{l}\text { - Sense of urgency } \\
\text { - Vision: ambition, } \\
\text { direction, purpose }\end{array}$ & & & & \\
\hline $\begin{array}{l}\text { 2. Policy and } \\
\text { implementation }\end{array}$ & $\begin{array}{l}\text { - Policy frames } \\
\text { - Programme } \\
\text { - 'Possibility space' to } \\
\text { experiment and } \\
\text { learn } \\
\text { - Information \& } \\
\text { communication } \\
\text { - } \text { Monitoring }\end{array}$ & & & & \\
\hline $\begin{array}{l}\text { 3. Responsibilities and } \\
\text { resources }\end{array}$ & $\begin{array}{l}\text { - Capacity (hours, } \\
\text { finances) } \\
\text { - Role-and } \\
\text { taskdescription }\end{array}$ & & & & \\
\hline
\end{tabular}

Figure 3. The full matrix of the governance scan (source: authors).

Step 3: Filling in the matrix

The next step is to fill the cells of the matrix, highlighted in green in Figure 2 and more in detail in Figure 3. The matrix is a composition of the above-mentioned governance aspects set against the governance design principles, which ultimately produces a matrix with 12 specific parts. To gain input for the matrix, we use two possible ways. The first is via experts interviews with relevant stakeholders in the governance process, the second being an online form these same stakeholders could fill in themselves to make the governance scan accessible and easy to use. The user is guided through the matrix step by step. The governance scan can be used to gain an overview of all kinds of governance aspects that need to be taken into account. In addition, this scan can be a means of communication between stakeholders by providing insight into the governance aspects that are satisfactory and where improvements are still possible.

For each step, a number of help questions have been drawn up that help to get an idea of what is meant by the combination of the governance aspects and governance principles. This extensive list of these guiding questions builds upon the questions asked in steps 1 and 
2. These questions provide direction, inspiration and clarification, but it is not necessary for the user to answer all questions. During expert interviews these questions are asked during the interview, but for the online form, it is possible for the user to fill in the answers to the questions that apply to their specific National Park.

Step 4: Value each cell

After filling in the matrix with a description of the situation in the National Park, it can be scored (either dark green, green or yellow) according to the degree of satisfaction with this situation. This should preferably be done with a number of key figures from the different levels and stakeholders. To clarify, as an example we take the cell at the top left of the matrix that concerns with "Vision and Story" (aspect 1) and Participation (principle A). In other words: to what extent are conceivable stakeholders involved in the development of the vision? The outcomes of question are summarized in the cell. Subsequently, a score can be applied ranging from very inclusive (dark green shaded or " ++ ") to partly inclusive (green shaded or "+") to exclusive for one or a small number of parties involved (yellow shaded or " $\mathrm{o}^{\prime \prime}$ ). This scoring activity needs to be done for each cell to get the whole overview.

Scoring the cells in the matrix is pre-eminently ${ }^{*}$ not ${ }^{*}$ about right or wrong. The point is that the matrix helps to clarify how people see the current governance system and/or how they would like to see the future system. The scoring is determined by what people see as the most ideal and optimal situation (in theory, or in the future) and how the practical situation relates to this. If this corresponds, the result will likely be a high score. If there is a mismatch, this will probably lead to a lower score.

\section{Results: Lessons Learned from 'New Land' National Park}

The governance scan explained above was applied in a real-life case setting, namely 'New Land' National Park in the province of Flevoland, the Netherlands [29]. It was established on 1 October 2018 and the National Park is currently managed by the organizations Flevo-landschap, Staatsbosbeheer, and Natuurmonumenten. The total surface area amounts to $289 \mathrm{~km}^{2}$ (112 sq $\mathrm{mi}$ ), of which over $75 \%$ is water. The land, mostly wetlands, is part of the artificial island called the Flevopolder. Nature reserves that are part of the National Park include the three lakes called 'Oostvaardersplassen', 'Lepelaarplassen', and 'Markermeer', and the artificial archipelago Marker Wadden. Some of those areas were already protected Natura 2000 sites before the park was established. The shift to becoming a National Park raised many governance related issues, in which the governance scan was used to assist in real life decision-making.

The purpose of our illustrative case in not to know all the details about what was found making use of the governance scan, but to provide the lessons we have learned using it in practice. After carefully going through all the steps of the governance scan that are described in this paper, the case of National Park New Land resulted in a matrix in which all the cells were discussed and valued. This leads to an overview of the current situation regarding governance processes and what is a desired system of governance according to the respondents, who together represented all directly involved stakeholders. Apart from the matrix is being used as an overview, it was also input for discussion among the stakeholders.

After applying the governance scan to 'New Land' National Park the following overarching observations have been made. Below we highlight the most crucial ones:

1. The governance scan showed that there is broad consensus among the stakeholders on the vision and story. All stakeholders generally agree that the nature and landscape values are the backbone for this National Park. The added value of this park is that these nature areas as well as its surroundings are predominantly man-made, which gives the park a unique selling point according to the stakeholders.

2. The level of organization around 'New Land' National Park is quite good as was indicated by the governance scan. The stakeholders involved know each other (very) well, collaborate on a regular basis and are all committed to the idea of establishing a 
National Park as well as its (future) management and development. Also, stakeholders agree to keep the number of organizations involved at first to a minimum so to pragmatically move forward and obtain the National Park status, to later expand the number of stakeholders to better include the private sector and community stakeholders.

3. In line with that the previous point: all stakeholders feel the urgency to get started with the National Park. Also, along with the ambition from the National government to establish 'National Parks of World Class', all stakeholders feel that creates momentum and a unique window of opportunity.

4. The governance scan also revealed that there are some issues where the stakeholders do not align. Although there is consensus on the vision, there are quite some different levels of ambition among the stakeholders. During the process of decision-making, these different have remain under the surface and had not yet been thoroughly discussed. The governance scan showed these different ambitions, which became input for discussion among the stakeholders involved.

5. A similar observation was diagnosed regarding the financial resources. Whereas all stakeholders are supportive on the idea of the National Park, the governance scan showed that a different level of ambitions also means that the stakeholders have divergent ideas on the financial resources they have available to invest in the National Park on a structural basis.

Where the first three observations showed common ground among the stakeholders, the two crucial latter observations showed where there is some uncertainty among the outcomes of the governance process. Taking these uncertainties as a starting point, fueled a collective, collaborative and interactive discussion, moderated by the authors of this paper, about the most ideal future scenarios and confronting these scenarios by discussing the likeliness of reaching these scenarios given scarce resource availability. The discussion helped to identify that the stakeholders had high (but also varying) ambitions as well as helped to identify that the collective resources were much scarcer than expected and the stakeholders expected the provincial government to largely take the (financial) lead. Eventually the National Park was officially established on 1 October 2018. Our governance scan played an important role in making the agreements and disagreement among stakeholders involved in the governance process explicitly and helped decision-makers to make better informed decisions.

\section{Discussion and Conclusions}

After designing the governance scan, describing the steps, and testing it in practice, we can subsequently zoom out and reflect on what this governance scan has brought about, what can be improved and how other National Parks elsewhere in the world can make use of it.

Our paper and underlying research started from theory, firstly to grasp the conceptual discussions about systems of governance in general and systems of governance of National Parks in particular, and secondly to develop a practical diagnostics tool that can be used in real-life cases by practitioners. Governance systems are quite complex as they include many actors and factors that are interrelated and influence each other. Offering typologies $[22,23]$ provides grip on this complexity and is helpful for policy and governance analysis. However, when looking at practice, we observe that this is always messier than in theory. The described 'ideal' types make the understanding of governance more tangible, but these typologies hardly exist one-on-one, while in real-life cases there is often a mix of different types. Mapping a governance system is therefore a challenging ambition. Nevertheless, we believe the governance scan presented in this paper offers a diagnostic tool, which is designed as such to make it practical to apply in practice, whilst still doing justice to and taking into account the complexity of the governance systems of National Parks by being firmly rooted in literature. Clearly, as a result of the goal to assist practitioners by means of the design of a pragmatic governance scan, a point of critique on the scan can obviously be that it simplifies the way National Parks are, or can be, governed. Being aware of this 
point, it does not take away the value of the pragmatic diagnostics tool can actually help practitioners to get a better overview of the current and future situation as is shown in the paper even though it might somewhat decease or simplify certain governance processes to helps the unravel this process and get more grip on it [11].

The governance scan can be used in three different ways, which makes it a handy diagnostic tool for a more tailor-made approach. First, it can be used in a descriptive way to determine the current (and desired) governance situation. Second, the tool can be use in an action-oriented way, making it suitable for decision-making and action taking. For example, the tool can be used to reveal what stakeholders perceive as good practices and what practices needs more attention. Such information, structured by the matrix that forms the basis of the governance scan, can assist decision-makers when they need to act and set priorities (green-yellow-red). Third, the tool is effective for making comparisons. Examining the difference between several governance systems of different National Parks and how such system plays out in practice can help practitioners to compare approaches, learn from each other and inform decisions and actions to enhance systems of governance.

The suggested process of valuation by scoring the cells of the matrix in 4 steps may seem deterministic and could be (mis)used or (mis)interpreted to make judgements about what is right or wrong. This is explicitly not the purpose of the approach. Rather, the purpose is to use the matrix helps to clarify how stakeholders of National Parks currently see or perceive the current governance system and/or how they would like to see the system in the (near) future. Regarding the latter, the scoring is determined by what people see as the most ideal and optimal situation (in theory, or in the future) and how the practical situation relates to this. Potentially there are gaps between the ideal and optimal solution and what is feasible and affordable in practice-in line with what the authors experience in the case of Nieuw Land National Park. Therefore, based on the experience already gained and discussed in this paper, we believe it might not be possible or even desirable to optimally "score" every subject in the matrix because this is practically not possible, feasible or even desirable. Scoring will indicate that choices have been made and it can help in making choices in the future.

We tried to make the governance scan into a diagnostics tool that is easy to use, ideally by practitioners themselves. Despite that the governance scan is a handy tool, applying the governance scan does require solid knowledge of the subject of "governance", for example to be able to follow the terminology and mastering the ability to ask additional or follow-up questions in conversations. This requires a good understanding of how the scan works-or a moderator with that knowledge and/or experience. Results can be enhanced by trying, learning and building experience with the governance scan. In our paper, we made the distinction between gaining the input via expert interviews or an online form. After using the tool in practice, we believe that the online form is a possibility, but largely to get a first impression. Givin the issues raised above, we think an approach led by a researcher (for expert interviews) or moderator (for interactive focus group discussions) with solid knowledge about governance are preferrable.

We can conclude that our governance scan works well as a diagnostic tool, helping users to provide an overview of governance systems in place, facilitating discussions among different stakeholders, and helping stakeholders to set priorities as is often relevant in decision-making processes. In its current form, it was successfully applied to the case of New Land National Park, located in The Netherlands, but we believe it is beneficial to other National Parks elsewhere in the world. Also, we believe the scan can be applied in a wider context than just National Parks, for instance to analyze other types of protected areas or any other area that is currently in the process of transition and looking for a sustainable way forward where balancing the goals of nature conservation and societal development can intertwine [30-32]. 
Author Contributions: Conceptualization, J.H.H. and S.H.; methodology, J.H.H. and S.H.; validation, J.H.H. and S.H.; formal analysis, J.H.H. and S.H.; investigation, J.H.H. and S.H.; resources, J.H.H. and S.H.; data curation, J.H.H. and S.H.; writing—original draft preparation, J.H.H. and S.H.; writingreview and editing, J.H.H. and S.H.; visualization, J.H.H. and S.H.; supervision, J.H.H. and S.H.; project administration, J.H.H. and S.H. All authors have read and agreed to the published version of the manuscript.

Funding: This research received no external funding.

Institutional Review Board Statement: Not applicable.

Informed Consent Statement: Not applicable.

Data Availability Statement: Data available on request.

Conflicts of Interest: The authors declare no conflict of interest.

\section{References}

1. Watson, J.; Dudley, N.; Segan, D.B.; Hockings, M. The performance and potential of protected areas. Nature 2014, 515, 67-73. [CrossRef] [PubMed]

2. $\quad$ Pleijte, M.; Systems, A.-S.K.; During, R.; Michels, R.; Policy, A.-B.A.; Wass; Landuse, L.G.E.A.; Milieu, W.N. Nationale Parken in Transitie: Governance-Implicaties van een Veranderend Beleidskader; Wettelijke Onderzoekstaken Natuur \& Milieu: Wageningen, The Netherlands, 2016. [CrossRef]

3. Cumming, G.S.; Allen, C.R. Protected areas as social-ecological systems: Perspectives from resilience and social-ecological systems theory. Ecol. Appl. 2017, 27, 1709-1717. [CrossRef]

4. Becken, S.; Job, H. Protected Areas in an era of global-local change. J. Sustain. Tour. 2014, 22, 507-527. [CrossRef]

5. Heslinga, J.; Groote, P.; Vanclay, F. Towards resilient regions: Policy recommendations for stimulating synergy between tourism and landscape. Land 2020, 9, 44. [CrossRef]

6. McCool, S.F.; Spenceley, A. Tourism and protected areas: A growing nexus of challenge and opportunity. Koedoe 2014, 56, 2. [CrossRef]

7. Hartman, S. Towards adaptive tourism areas? A complexity perspective to examine the conditions for adaptive capacity. $J$. Sustain. Tour. 2015, 24, 299-314. [CrossRef]

8. Hartman, S. Destination governance in times of change: A complex adaptive systems perspective to improve tourism destination development. J. Tour. Futur. 2021. ahead of print. [CrossRef]

9. Bosak, K.; McCool, S.F. A research agenda for sustainable tourism: Some ideas worth pursuing. In A Research Agenda for Sustainable Tourism; McCool, S.F., Bosak, K., Eds.; Edward Elgar Publishing: Cheltenham, UK, 2019.

10. Borrini-Feyerabend, G.; Dudley, N.; Jaeger, T.; Lassen, B.; Pathak Broome, N.; Phillips, A.; Sandwith, T. Governance of Protected Areas: From Understanding to Action. Best Practice Protected Area Guidelines Series No. 20; IUCN: Gland, Switzerland, 2013.

11. Wesley, A.; Pforr, C. The governance of coastal tourism: Unravelling the layers of complexity at Smiths Beach, Western Australia. J. Sustain. Tour. 2010, 18, 773-792. [CrossRef]

12. Swyngedouw, E. Governance innovation and the citizen: The janus face of governance-beyond-the-state. Urban Stud. 2005, 42, 1991-2006. [CrossRef]

13. Hartman, S.; Parra, C.; De Roo, G. Stimulating spatial quality? Unpacking the approach of the province of Friesland, the Netherlands. Eur. Plan. Stud. 2015, 24, 297-315. [CrossRef]

14. North, D.C. Institutions, Institutional Change, and Economic Performance; Cambridge University Press: Cambridge, UK, 1990.

15. Hajer, M. Policy without polity? Policy analysis and the institutional void. Policy Sci. 2003, 36, 175-195. [CrossRef]

16. Ostrom, E. Beyond markets and states: Polycentric governance of complex economic systems. Am. Econ. Rev. 2010, 100, 641-672. [CrossRef]

17. Olsson, P.; Gunderson, L.H.; Carpenter, S.R.; Ryan, P.; Lebel, L.; Folke, C.; Holling, C.S. Shooting the rapids: Navigating transitions to adaptive governance of social-ecological systems. Ecol. Soc. 2006, 11, 18. [CrossRef]

18. Lebel, L.; Anderies, J.M.; Campbell, B.; Folke, C.; Hatfield-Dodds, S.; Hughes, T.; Wilson, J. Governance and the capacity to manage resilience in regional social-ecological systems. Ecol. Soc. 2006, 11, 19. [CrossRef]

19. Castro-Arce, K.; Parra, C.; Vanclay, F. Social innovation, sustainability and the governance of protected areas: Revealing theory as it plays out in practice in Costa Rica. J. Environ. Plan. Manag. 2019, 62, 2255-2272. [CrossRef]

20. Parra, C. Sustainability and multi-level governance of territories classified as protected areas in France: The Morvan Regional Park case. J. Environ. Plan. Manag. 2010, 53, 491-509. [CrossRef]

21. Eagles, P.F. Governance of recreation and tourism partnerships in parks and protected areas. J. Sustain. Tour. 2009, 17, 231-248. [CrossRef]

22. Borrini-Feyerabend, G.; Bueno, P.; Hay-Edie, T.; Lang, B.; Rastogi, A.; Sandwith, T. A Primer on Governance for Protected and Conserved Areas, Stream on Enhancing Diversity and Quality of Governance; IUCN: Gland, Switzerland, 2014.

23. Hall, C.M. A typology of governance and its implications for tourism policy analysis. J. Sustain. Tour. 2011, 19, 437-457. [CrossRef] 
24. Folke, C.; Hahn, T.; Olsson, P.; Norberg, J. Adaptive governance of social-ecological systems. Annu. Rev. Environ. Resour. 2005, 30, 441-473. [CrossRef]

25. Kemp, R.; Loorbach, D.; Rotmans, J. Transition management as a model for managing processes of co-evolution towards sustainable development. Int. J. Sustain. Dev. World Ecol. 2007, 14, 78-91. [CrossRef]

26. Bosak, K. Tourism, development, and sustainability. In Reframing Sustainable Tourism. Environmental Challenges and Solutions; McCool, S., Bosak, K., Eds.; Springer: Dordrecht, The Netherlands, 2016; pp. 33-44. [CrossRef]

27. Lockwood, M. Good governance for terrestrial protected areas: A framework, principles and performance outcomes. J. Environ. Manag. 2010, 91, 754-766. [CrossRef] [PubMed]

28. Hartman, S. Adaptive tourism areas in times of change. Ann. Tour. Res. 2020, 87, 102987. [CrossRef] [PubMed]

29. National Park Nieuw Land. Available online: https:/ / www.nationaalparknieuwland.nl/nl (accessed on 28 July 2021).

30. Heslinga, J.H.; Groote, P.D.; Vanclay, F. Using a social-ecological systems perspective to understand tourism and landscape interactions in coastal areas. J. Tour. Futur. 2017, 3, 23-38. [CrossRef]

31. Heslinga, J.; Groote, P.; Vanclay, F. Strengthening governance processes to improve benefit-sharing from tourism in protected areas by using stakeholder analysis. J. Sustain. Tour. 2017, 27, 773-787. [CrossRef]

32. Snyman, S.; Bricker, K.S. Living on the edge: Benefit-sharing from protected area tourism. J. Sustain. Tour. 2018, 27, 705-719. [CrossRef] 